\title{
Effect of Mixed Microbial Culture on Fermentation of Beverage Residues and the Effect of the Fermented Beverage Residues on in Vitro Rumen Fermentation and Methane Production
}

\author{
N. D. Senevirathne, T. Okamoto, J. Takahashi, K. Umetsu, and T. Nishida
}

\begin{abstract}
The aim of this study was to increase the nutritive value of coffee, green and oolong tea residues and assess if the fermented residues have the potential to mitigate enteric methane emissions. A mixed microbial culture $(20 \mathrm{~g} / \mathrm{kg})$ was added to each residue and the mixture incubated for $3 \mathrm{~d}$ at $35^{\circ} \mathrm{C}$ (anaerobically) and 2 weeks at $30^{\circ} \mathrm{C}$ (aerobically). Unfermented and fermented beverage residues were assayed for their saccharide and ethanol content. Four separate total mixed rations (TMR) were prepared using the three fermented beverage residues and hay (control). The fermented residues ( 2 g dry matter (DM)) were individually mixed with hay ( 3 g DM) and concentrate $(5 \mathrm{~g} \mathrm{DM})$ and the in vitro rumen methane output was quantified during the $24 \mathrm{~h}$ incubation period using the continuous gas quantification system. The fermented residues of coffee, oolong tea and green tea had higher concentrations of cellotriose, cellobiose and xylobiose than the corresponding unfermented residues. Ethanol concentration was higher in the fermented coffee and green tea residues than in their respective unfermented residues. The methane output ( $\mathrm{L} \mathrm{CH4/24} \mathrm{h)} \mathrm{from} \mathrm{the} \mathrm{TMR} \mathrm{containing} \mathrm{fermented} \mathrm{residues} \mathrm{of}$ coffee $(0.118 \mathrm{~L})$, oolong tea $(0.127 \mathrm{~L})$ and hay (control; $0.123 \mathrm{~L}$ ) did not differ, but the methane output was lower for all compared to the TMR containing fermented green tea residue $(0.141 \mathrm{~L})$. The results suggest that fermented coffee, oolong tea and green tea residues are a potentially good source of protein and energy, and fermented residues of coffee caused a numerical decrease methane output.
\end{abstract}

Index Terms-Beverage residues, in vitro, methane, mixed microbial culture.

\section{INTRODUCTION}

Over the last decade, livestock farmers have faced the problem of acquiring affordable feed for their livestock. Hence, agricultural and industrial by-products have been suggested as one of the solutions. However, this feed source is usually of low quality and the some of these by-products may have a negative effect on animal production [1], because of their low nitrogen and high fiber content. The high fiber content prevents assess of ruminal hydrolytic enzymes to cellulose and hemicellulose [2], [3]. During recent years, mixed microbial culture and their fibrolytic enzymes have

Manuscript received August 6, 2012; revised September 15, 2012.

T. Nishida, N. D. Senevirathne, J. Takahashi, and K. Umetsu are with the Department of Animal and Food Hygiene, Obihiro University of Agriculture and Veterinary Medicine, Obihiro, Hokkaido 080 8555, Japan (Tel.:+81155-49-5455, e-mail: nishtake@ obihiro.ac.jp).

T. Okamoto is with the Meiwa sangyo Co. Ltd. Nishi 7jyo, Nishi-Ishigatsubo-cho, 7-4, Shimogyo-ku, Kyoto, 600 8896, Japan. been used to improve the nutritive value and utilization efficiency of low-quality roughages. Agricultural by-products are produced in large quantities throughout the world and could potentially consist of nutrients to form part of the ruminant diet. With coffee and tea being some of the most common beverages consumed daily around the world, the safe disposal of large quantities of unused residues in the producing countries is challenging and the release of these residues into the environment is causing enormous problems. In addition, methane output from beverage residues mixed total ration on in vitro fermentation represents a loss of energy to the host animal [4], and [5] contributes to global greenhouse gas emissions [6]. Therefore, the objectives of this study were to evaluate the effect of a mixed microbial culture treatment on the nutritive value of coffee, green tea and oolong tea beverage residues and the effect of the fermented residues on in vitro rumen fermentation and methane production.

\section{MATERIALS AND METHODS}

A mixed microbial culture $(20 \mathrm{~g} / \mathrm{kg}$ dry matter (DM); Bio-PKC ${ }^{\circledast}$, Marubeni Corporation, Tokyo, Japan) was mixed separately with $1 \mathrm{~kg}$ of coffee, green tea and oolong tea residues, placed into sealable bags and incubated for $3 \mathrm{~d}$ at $35^{\circ} \mathrm{C}$ (anaerobically) and 2 weeks at $30^{\circ} \mathrm{C}$ (aerobically).

\section{A. Sample Preparation and in Vitro Fermentation}

The fermented beverage residues were oven-dried at $60^{\circ} \mathrm{C}$ for $48 \mathrm{~h}$ and stored under dry, cool, dark conditions in sealed containers prior to use. Four total mixed rations (TMR) were prepared that contained either a beverage residue or hay (200 $\mathrm{g} / \mathrm{kg} \mathrm{DM})$ and hay $(300 \mathrm{~g} / \mathrm{kg} \mathrm{DM})$ and concentrate $(500 \mathrm{~g} / \mathrm{kg}$ $\mathrm{DM})$. The TMR treatments evaluated were: hay (Control-TMR), coffee residue (C-TMR), green tea residue (G-TMR), and oolong tea residue (O-TMR). The effects of each TMR treatment (10 g DM) on rumen fermentation were tested in vitro for $24 \mathrm{~h}$ at $39^{\circ} \mathrm{C}$ using the continuous gas quantification system as previously described by [7]. Briefly, samples of rumen fluid were obtained from two non-lactating Holstein cows prior to morning feeding, strained and combined on an equal volume basis. Buffer was prepared according to reference [8], sterilized by autoclaving and flushed with $\mathrm{CO}_{2}$ for $1 \mathrm{~h}$ prior to being dispensed into each fermentation jar. Rumen fluid was added to buffer at a ratio of 1:4. Samples of the incubation medium were collected at intervals of $0,2,4,8$ and $24 \mathrm{~h}$ and stored at $-20^{\circ} \mathrm{C}$ for 
subsequent ammonia-N $\left(\mathrm{NH}_{3}-\mathrm{N}\right)$ and volatile fatty acid (VFA) analysis. At the end of each $24 \mathrm{~h}$ incubation period, all incubations were stopped, the contents were discharged, and the fermenters were thoroughly washed and autoclaved. The fermenters were then re-charged with fresh buffer and inoculum to begin the next $24 \mathrm{~h}$ incubation period. The experiment was repeated four times in total with treatments randomly assigned to incubation jars for each incubation period.

\section{B. Volatile Fatty Acids and Methane Analysis}

Volatile fatty acid concentrations were determined by gas chromatography (GC-2014, Shimadzu, Kyoto, Japan) equipped with a flame-ionization detector and a capillary column (ULBON HR-52, $0.53 \mathrm{~mm}$ ID $\times 30 \mathrm{~m}, 3.0 \mu \mathrm{m}$ ) using 2-ethyl-n-butyric acid as an internal standard and samples were prepared for analysis according to [7]. Methane output from each fermentation jar was continuously measured by infrared analyzer (Ex air, Yokogawa, Tokyo, Japan) using the in vitro continuous gas quantification system (Takasugi Seisakusho, Tokyo, Japan) and all data were pooled to a computer interface at $1 \mathrm{~min}$ intervals. The $\mathrm{pH}$ and oxidation reduction potential (ORP) were measured using a $\mathrm{pH}$ and ORP meter (HM-21P, Toa electronics Ltd., Tokyo, Japan).

\section{Chemical Analysis}

Unfermented and fermented beverage residues were dried at $60^{\circ} \mathrm{C}$ for $48 \mathrm{~h}$ in a forced-air oven and then ground through a $1 \mathrm{~mm}$ sieve. Samples were stored at room temperature in sealed containers. Duplicate samples of each residue were assayed for DM, crude protein (CP), organic matter (OM), neutral detergent fibre (NDF) and acid detergent fibre (ADF). Dry matter and $\mathrm{OM}$ of the samples were determined according to the AOAC procedures [9]. Nitrogen $(N)$ was determined by the Kjeldahl method [9] using an electrical heating digester (FOSS tecator ${ }^{\mathrm{TM}}$ Digester, Tokyo, Japan) and an automatic distillation apparatus (FOSS kjeltec ${ }^{\mathrm{TM}} 2100$, Tokyo, Japan), and then CP was determined as $N \times 6.25$. Neutral detergent fibre and ADF were determined according to the methods as in [10]. The concentrations of individual saccharides were determined by high performance liquid chromatography (HPLC) as described by [11]. Ammonia-N concentration in the incubation medium was analyzed according to the procedure of [12].

\section{Statistical Analysis}

Data were analyzed by one-way analysis of variance (ANOVA) using PROC GLM in SAS statistical software version 9.2 [13]. Differences among means were identified using Tukey multiple comparisons. Effects were considered significant when $P<0.05$.

\section{RESULTS AND DISCUSSION}

\section{A. Saccharides and Ethanol Concentration of Unfermented and Fermented Beverage Residues}

TABLE I: SACCHARIDES AND ETHANOL CONCENTRATION (MG/G ORGANIC MATTER) OF UNFERMENTED AND FERMENTED BEVERAGE RESIDUES.

\begin{tabular}{|c|c|c|c|c|c|c|c|c|}
\hline \multirow[t]{2}{*}{ Type } & \multirow[t]{2}{*}{ Treatment } & \multicolumn{7}{|c|}{ Variables } \\
\hline & & Cell & Cellb & Xylb & Xyl & Arab & Glu & Ethnl \\
\hline \multirow[t]{4}{*}{ Coffee } & Unfermented & 0.03 & 0.01 & 0.01 & 0.03 & 0.01 & ND & 0.01 \\
\hline & Fermented & 5.06 & 2.20 & 0.99 & 1.34 & 2.52 & ND & 1.89 \\
\hline & S.E.M. & 0.038 & 0.038 & 0.011 & 0.002 & 0.823 & - & 0.021 \\
\hline & $\mathrm{P}$ & 0.01 & 0.02 & 0.01 & 0.21 & 0.38 & - & 0.01 \\
\hline \multirow{4}{*}{$\begin{array}{l}\text { Green } \\
\text { tea }\end{array}$} & Unfermented & 1.15 & 0.14 & 0.54 & 0.14 & 0.33 & 0.10 & 0.03 \\
\hline & Fermented & 3.81 & 4.36 & 11.87 & 9.09 & 1.90 & 5.13 & 8.50 \\
\hline & S.E.M. & 0.070 & 0.049 & 0.106 & 0.254 & 0.251 & 0.328 & 0.777 \\
\hline & $\mathrm{P}$ & 0.01 & 0.01 & 0.04 & 0.21 & 0.09 & 0.01 & 0.02 \\
\hline \multirow{4}{*}{$\begin{array}{l}\text { Oolong } \\
\text { tea }\end{array}$} & Unfermented & 0.01 & 0.07 & 0.02 & 0.01 & 0.01 & 0.06 & ND \\
\hline & Fermented & 5.42 & 4.75 & 3.33 & 1.88 & 1.66 & 3.81 & 1.09 \\
\hline & S.E.M. & 0.116 & 0.042 & 0.074 & 0.060 & 0.055 & 0.024 & 0.770 \\
\hline & $\mathrm{P}$ & 0.03 & 0.01 & 0.03 & 0.04 & 0.04 & 0.009 & 0.57 \\
\hline
\end{tabular}

Cell, cellotriose; Cellb, cellobiose; Xylb, xylobiose; Xyl, xylose; Arab, arabinose; Glu, glucose; Ethnl, ethanol; ND, not detected; S.E.M, standard error of the mean.

The saccharides and ethanol concentration of unfermented and fermented beverage residues are presented in Table I. The fermented residues of coffee, oolong tea and green tea had higher $(P<0.05)$ concentrations of cellotriose, cellobiose and xylobiose than the unfermented residue of each beverage. In addition, fermented oolong tea residues were higher in arabinose $(P=0.04)$, glucose $(P=0.009)$ and xylose $(P=0.04)$ compared to its unfermented residue. The high concentration of saccharides may be associated with ligno-cellulolytic enzymes produced by microbes during anaerobic and aerobic fermentation [14]. There was higher ethanol concentration in the fermented coffee, green and oolong tea residues than their unfermented residues. Higher ethanol production might have been stimulated by yeasts contained in the MMC during aerobic fermentation. It has been reported that greater ethanol production can be seen during aerobic fermentation when sufficient amount of sugars are available for yeast to maintain their metabolism [15]-[17].

\section{A. Chemical Composition of Unfermented and Fermented Beverage Residues}

The chemical compositions of unfermented and fermented beverage residues are presented in Table II. The CP concentration did not differ $(P>0.05)$ for any of the beverage 
residues after MMC fermentation. However, the $\mathrm{CP}$ concentration in both the unfermented (range, 131.7 - 304.1 $\mathrm{g} / \mathrm{kg} \mathrm{DM}$ ) and fermented (range, $140.0-312.6 \mathrm{~g} / \mathrm{kg} \mathrm{DM}$ ) residues was high, and therefore these residues are a potentially good source of protein for livestock. Coffee and tea residues can contain tannins, which might explain the lack of an increase in CP due to MMC fermentation. In addition, the maillard reaction and heat damage could occur during beverage production under high heat. Referece [18], and [19] have indicated these reactions and damages that are highly resistant to microbial enzyme to cell wall degradation. Hence, this might be another reason for a lack of an increase in CP in fermented residues. Neutral detergent fibre was reduced in fermented green $(P=0.01)$ and oolong tea $(P=0.05)$ residues compared to their unfermented residues. This result agrees with the findings of [20] and [21] who suggested that the reduction in NDF could be due to the stabilization characteristics of the microbial inoculant. Acid detergent fibre concentration was lower $(P=0.006)$ for the fermented than unfermented coffee residue.

\section{B. In Vitro Rumen Fermentation Characteristics}

In vitro rumen methane output, carbon dioxide output $\left(\mathrm{CO}_{2}\right), \mathrm{NH}_{3}-\mathrm{N}$ concentration, $\mathrm{pH}$, ORP and VFA production after $24 \mathrm{~h}$ incubation are displayed in Table III. The methane output $\left(\mathrm{L} \mathrm{CH}_{4} / 24 h\right)$ from C-TMR $(0.118 \mathrm{~L})$, O-TMR $(0.127$ $L)$, and Control-TMR $(0.123 L)$ did not differ from one another, but the methane output was lower for all compared to G-TMR $(0.141 \mathrm{~L})$. The increase in $\mathrm{CH}_{4}$ output observed for G-TMR may reflect the increase in DM of the fermented residue. It is known that higher fibre concentrations in a diet can increase the $\mathrm{CH}_{4}$ output [22]. There was a numerically lower $\mathrm{CH}_{4}$ output with C-TMR compared to the other TMR treatments. Coffee residues contain considerable amounts of phenolic compounds such as tannins, saponins and caffeine [1], [23]-[26]. Reference [25] observed that tannin-containing forage diets have the potential to reduce $\mathrm{CH}_{4}$ emissions in ruminants. In addition, saponins can improve rumen fermentation and nitrogen metabolism [27]. Furthermore, saponins may inhibit rumen methanogen populations through a reduction in protozoa numbers [28], because methanogens have both ecto- and endo-symbiotic relationships with protozoa [29]. Consequently, methanogen species associated with protozoa usually decrease with decreasing protozoa numbers [30]. Methanogens associated with protozoa may account for decreased $\mathrm{CH}_{4}$ emission [31]

TABLE II: Dry MATter (DM, G/KG), CRUde Protein (CP), ORGANIC MATTER (OM), NEUTRAL DETERGENT FIBRE (NDF) AND ACID DETERGENT FIBRE (ADF) (G/KG DM) COMPOSITION OF UNFERMENTED AND FERMENTED BEVERAGE RESIDUES.

\begin{tabular}{|c|c|c|c|c|c|c|}
\hline \multirow[t]{2}{*}{ Type } & \multirow[t]{2}{*}{ Treatment } & \multicolumn{5}{|c|}{ Variables } \\
\hline & & DM & $\mathrm{CP}$ & $\mathrm{OM}$ & $\mathrm{NDF}$ & $\mathrm{ADF}$ \\
\hline \multirow[t]{4}{*}{ Coffee } & Unfermented & 956.5 & 131.7 & 983.2 & 333.1 & 458.9 \\
\hline & Fermented & 982.5 & 140.0 & 988.1 & 332.5 & 353.4 \\
\hline & S.E.M. & 0.10 & 0.17 & 0.03 & 0.03 & 0.04 \\
\hline & $\mathrm{P}$ & 0.05 & 0.25 & 0.09 & 0.44 & 0.006 \\
\hline \multirow{4}{*}{$\begin{array}{l}\text { Green } \\
\text { tea }\end{array}$} & Unfermented & 952.0 & 304.1 & 962.7 & 411.4 & 336.6 \\
\hline & Fermented & 963.4 & 312.6 & 958.7 & 550.3 & 245.0 \\
\hline & S.E.M. & 0.01 & 0.90 & 0.20 & 0.10 & 0.47 \\
\hline & $\mathrm{P}$ & 0.02 & 0.54 & 0.49 & 0.01 & 0.07 \\
\hline \multirow{4}{*}{$\begin{array}{l}\text { Oolon } \\
\mathrm{g} \\
\text { tea }\end{array}$} & Unfermented & 921.5 & 208.7 & 957.0 & 548.8 & 298.3 \\
\hline & Fermented & 965.6 & 214.0 & 956.3 & 465.5 & 294.6 \\
\hline & S.E.M. & 0.23 & 0.79 & 0.06 & 0.31 & 0.25 \\
\hline & $\mathrm{P}$ & 0.07 & 0.84 & 0.55 & 0.05 & 0.53 \\
\hline
\end{tabular}

S.E.M, standard error of the mean.

TABLE III: IN VITRO METHANE (CH4) OUTPUT, AMMONIA-N (NH3-N) CONCENTRATION, PH AND VOLATILE FATTY ACID (VFA) PRODUCTION FROM TOTAL MiXED RATIONS (TMR) AFTER 24 H INCUBATION.

\begin{tabular}{|c|c|c|c|c|c|c|}
\hline & Control TMR & Coffee TMR & Green tea TMR & Oolong tea TMR & S.E.M. & $\mathrm{P}$ \\
\hline $\mathrm{CH}_{4}(\mathrm{~L} / 24 \mathrm{~h})^{1}$ & $0.123^{\mathrm{b}}$ & $0.118^{\mathrm{b}}$ & $0.141^{\mathrm{a}}$ & $0.127^{\mathrm{b}}$ & 0.003 & 0.009 \\
\hline $\mathrm{CO}_{2}(\mathrm{~L} / 24 \mathrm{~h})^{1}$ & $1.57^{\mathrm{b}}$ & $1.41^{\mathrm{b}}$ & $2.41^{\mathrm{a}}$ & $1.47^{\mathrm{a}}$ & 0.222 & 0.008 \\
\hline $\mathrm{NH}_{3}-\mathrm{N}(\mathrm{mg} / \mathrm{L})^{1}$ & 37.44 & 39.22 & 35.77 & 29.13 & 3.311 & 0.528 \\
\hline $\mathrm{pH}^{2}$ & 6.86 & 6.84 & 6.69 & 6.82 & 0.066 & 0.600 \\
\hline $\mathrm{ORP}^{2}(\mathrm{mV})$ & -399.75 & -394.50 & -418.75 & -393.75 & 10.52 & 0.706 \\
\hline Total VFA $(\mathrm{mM})^{1}$ & 37.95 & 39.43 & 48.30 & 37.49 & 4.431 & 0.307 \\
\hline \multicolumn{7}{|l|}{$\operatorname{VFA}(\mathrm{mM})^{1}$} \\
\hline Acetic (A) & 26.69 & 27.43 & 33.50 & 27.07 & 3.526 & 0.422 \\
\hline Propionic $(\mathrm{P})$ & 10.54 & 11.38 & 14.03 & 9.84 & 1.033 & 0.086 \\
\hline Butyric & $0.714^{\mathrm{ab}}$ & $0.623^{\mathrm{ab}}$ & $0.770^{\mathrm{a}}$ & $0.573^{\mathrm{b}}$ & 0.040 & 0.048 \\
\hline $\mathrm{A}: \mathrm{P}$ ratio & 2.49 & 2.42 & 2.51 & 2.64 & 0.214 & 0.493 \\
\hline
\end{tabular}

${ }^{1}$ Mean values after $24 \mathrm{~h}$ incubation $(\mathrm{n}=4)$. ${ }^{2}$ Mean values over the $24 \mathrm{~h}$ incubation period $(n=4)$.

${ }^{\mathrm{a}-\mathrm{b}}$ means within a row with different superscripts are significantly differ $(P<0.05)$.

The carbon dioxide output $\left(\mathrm{L} \mathrm{CO}_{2} / 24 \mathrm{~h}\right)$ from C-TMR (1.41 L), O-TMR $(1.47 \mathrm{~L})$, and Control-TMR $(1.57 \mathrm{~L})$ were not significantly different, but the $\mathrm{CO}_{2}$ output of G-TMR
$(2.41 \mathrm{~L})$ was significantly different. The increase in $\mathrm{CO}_{2}$ output may reflect the increase the $\mathrm{CP}$ content of the fermented G-TMR. In addition $\mathrm{CO}_{2}$ is an end product of 
lactate fermentation to propionate via the succinate fermentation partway by the ruminal bacterium [32]. Therefore the increase $\mathrm{CO}_{2}$ production might promote growth and activities of rumen microorganisms in the fermentation jars. Concentrations of ammonia-N, total VFA (tVFA), acetic acid (A), and propionic acid (P), and $\mathrm{pH}$ did not differ between TMR treatments, but the G-TMR had a numerically higher concentration of tVFA than the other TMR treatments. The addition of agricultural by-products to the diet of livestock may enhance the VFA concentration [33]. Reference [34] reported that, roughage based diets might increase the tVFA and decrease the A:P ratio. Both reference [25], and [35] reported that tVFA varies with the response to phenolic compounds in the diet by depressing fibre degradation, with the extent of which depends upon the chemical structure of the phenolic compound and the species of methanogen [36]. Although not observed in this study, reference [7] reported that an increasing $\mathrm{pH}$ might decrease tVFA. In a study to determine the fermentation quality of TMR silage containing coffee residues, butyric acid was not detected because of the inhibition of its production by coffee residues [37]. Whereas, in this study, butyric acid was detected and concentrations differed across treatments $(P=0.048)$. Butyric acid concentration was higher $(P=0.048)$ in G-TMR than O-TMR and neither of those two residues differed to the Control-TMR and C-TMR. Oxidation reduction potential can change slightly with the substrate type [38] and it is an indicate measure of the microbial activity. Rumen is anaerobic condition with potentially negative ORP [39], [40]. In this study, ORP did not change between TMR treatments but G-TMR had a numerically lower value.

\section{CONCLUSION}

Beverage by-products such as coffee, oolong tea, and green tea residues are a good potential source of energy and protein. Moreover, the methane output of C-TMR was numerically lower than the other TMR treatments. By fermenting coffee, oolong tea and green tea by-products with a mixed microbial culture, these beverage residues have the potential to help eliminate some of environmental pollution problems that exist today in coffee and tea producing countries, as well as provide an affordable feed for livestock. However, the current use of beverage by-products is limited due to their high phenolic acid content. Therefore, further research is needed to determine the dry matter intake, the health implications of feeding beverage residues, the appropriate method of offering the feedstuffs and the optimum levels of incorporation into diets.

\section{REFERENCES}

[1] S. I. Solange, E. M. S. Machado, M. Silva, and J. A. Teixeira, "Production, composition, and application of coffee and its industrial residues," Food Bioprocess technol., vol. 4, pp. 661-672, Mar. 2011.

[2] A. Chesson, "Microbiology of the rumen in relation to the chemical or biological treatment of crops and by-products," in proc. Second seminar on the upgrading of crops and by-products: improvements in the nutritive value of crops and by-products by chemical or biological treatments. Ministry of Agriculture, Fisheries and food, London UK, 1984, pp. 1-10.
[3] Z. L. Tan, H. P. Chen, L. H. He, R. J. Fang, and T. X. Xing, "Variation in the nutritional characteristics of wheat straw," Anim. Feed. Sci. Technol., vol. 53, pp. 337-344, Aug. 1995.

[4] J. B. Holter and A. J. Youg, "Methane prediction in dry and lactating Holstein cows," J. Dairy Sci., vol. 75, pp. 2165-2175, Aug. 1992.

[5] K. A. Johnson and D. E. Johnson, "Methane emission from cattle," $J$. Anim. Sci., vol. 73, pp. 2483-2492, Mar.1995.

[6] A. R. Moss, J. Jouany, and J. Newbold, "Methane production by ruminants: its contribution to global warming," Ann. Zootec., vol. 49, pp. 231-253, April 2000.

[7] C. Sar, B. Mweny, B. Santoso, K. Takaura, R. Morikawa, N. Isogai, Y Asakura, Y. Toride, and J. Takahashi, "Effect of Escherichia coli W3110 on ruminal methanogenesis and nitrate/nitrite reduction in vitro," Anim. Feed Sci. Technol., vol. 118, pp. 295-306, Oct. 2005.

[8] E. I. McDougall, "Studies on ruminant saliva. I. The composition and output of sheep's saliva," Biochem. J, vol. 43, pp. 99-109, Oct. 1984.

[9] AOAC, "Official methods of analysis," 16th ed. Association of Official Analytical Chemists, Arlington, VA, USA. 1995.

[10] P. J. Van Soest, J. B. Robertson, and B. A. Lewis, "Methods for dietary fibre, neutral detergent fibre, and non-starch polysaccharides in relation to animal nutrition," J. Dairy sci., vol. 74, pp. 3583-3597, Oct. 1991.

[11] T. Shao, N. Ohba, M. Shimojo, and Y. Masuda, "Dynamics of early fermentation of Italian ryegrass (Lolium multiflorum Lam.) silage," Asian-Aust. J. Anim. Sci, vol. 17, pp. 808-813, Jun. 2002.

[12] E. J. Conway and E. O'Malley, "Micro diffusion methods: ammonia and urea using buffered absorbents," (revised methods for ranges greater than 10ugN), Biochem. J., vol, 36, pp. 655-661, June 1945.

[13] SAS Institute, SAS enterprise guide: version 9.2, SAS Inst., Cary, NC 2010.

[14] R. Cohen, L. Persky, and Y. Hadar, "Biotechnological applications and potential of wood-degrading mushrooms of the genus pleurotus," Appl. Microbiol. Biotechnol., vol. 58, pp. 582-594, Feb 2002.

[15] A. R. Henderson and P. McDonald, "Effect of formic acid on the fermentation of grass of low dry matter content," J. Sci. Food Agric., vol. 22, pp. 157-163, April 1971.

[16] F. Driehuis, P. G. Van, A. M. Wikselaar, V. Vuuren, and S. F. Spoelstra "Effect of a bacterial inoculant on rate of fermentation and chemical composition of high dry matter grass silage," J. Agric. Sci., vol. 128, pp. 323-329, May 1997.

[17] Z. G. Weinberg, G. Ashbell, and G. Azrieli, "The effect of applying lactic acid bacteria at ensilage on the chemical and microbiological composition of vetch, wheat and alfalfa silages," J. Appl. Microbial. vol. 64, pp. 1-7, Mar. 1988

[18] A. A. C. Tavares, M. N. Pereira, M. R. Tavares, and M. L. Chaves, "Performance of Holstein Zebu cows under partial replacement of corn by coffee hull," Sci. Agric. (Piracicaba Braz.), vol. 62, pp. 95-101, Apr. 2005.

[19] U. Krishnamoorthy, C. J. Sniffen, M. D. Stern, and P. J. Van Soest, "Evaluation of a mathematical model of rumen digestion and an in vitro simulation of rumen proteolysis to estimate the rumen-undegraded nitrogen content of feedstuffs," Br. J. Nutr., vol. 50, pp. 555-568, Nov. 1983.

[20] R. Umana, C. R. Staples, D. B. Bates, C. J. Wilcox, and W. C. Mahana, "Effects of a microbial inoculant and sugarcane molasses on the fermentation, aerobic stability and digestibility of Bermuda grass ensiled at two moisture contents," J. Anim. Sci., vol. 69, pp. 4588-4601, Nov. 1991

[21] T. Aksu, E. Baytok, and D. Bolat, "Effects of a bacterial silage inoculant on corn silage fermentation and nutrient digestibility," Small Rumin. Res., vol. 55, pp. 249-252, Dec. 2003.

[22] K. L. Blaxter and J. L. Clapperton, "Prediction of the amount of methane produced by ruminants," Br. J. Nutr., vol. 19, pp. 511-522, Aug. 1965.

[23] C. C. Xu, Y. Cai, N. Moriya, and M. Ogawa, "Nutritive value for ruminants of green tea grounds as a replacement of brewers' grains in totally mixed ration silage," Anim. Feed Sci. Technol., vol. 138, pp. 228-238, Nov. 2006.

[24] H. D. Belitz, W. Grosch, and P. Schieberle, "Coffee, tea, cocoa," in Food Research International, H. D. Belitz, W. Grosch, and P. Schieberle Ed. 2009, ch 29, pp. 185-189.

[25] R. Puchala, B. R. Min, A. L. Goetsch, and T. Sahlu, "The effect of a condensed tannin containing forage on methane emission by goats," $J$. Anim. Sci., vol. 83, pp. 182-186, Oct. 2005.

[26] T. Negesse, H. P. S. Makkar, and K. Becker, "Nutritive value of some non-conventional feed resources of Ethiopia determined by chemical analyses and an in vitro gas method," Anim. Feed Sci. Technol., vol 154, pp. 204-217, Nov. 2009 
[27] R. J. Wallace, "Antimicrobial properties of plant secondary metabolites," Proc. Nutr. Soc., vol. 63, pp. 621-629, Nov. 2004.

[28] Y. Q. Guo, J. X. Liu, Y. Lu, W. Y. Zhu, S. E. Denman, and C. S McSweeney, "Effect of tea saponin on methanogenesis, microbial community structure and expression of mcrA gene, in cultures of rumen micro-organisms," Lett. Appl. Microbiol., vol. 47, pp. 421-426, Nov. 2008.

[29] B. J. Finlay, G. Esteban, K. J. Clarke, A. G. Williams, T. M. Embley, and R. R. Hirt, "Some rumen ciliates have endo-symbiotic methanogens," FEMS Microbiol Lett., vol. 117, pp. 157-162, April 1994.

[30] R. Sharp, C. J. Ziemer, M. D Stern, and D. A. Stahl, “Taxon-specific associations between protozoal and methanogen populations in the rumen and a model rumen system," FEMS Microbiol. Ecol., vol. 26, pp. 71-78, May 1998.

[31] C. J. Newbold, B. Lassalas, and J. P. Jouany, "The importance of methanogenesis associated with ciliated protozoa in ruminal methane production in vitro," Lett. Appl. Microbiol., vol. 21, pp. 230-234, Oct 1995.

[32] R. I. Mackie, F. M. C. Gilcrist, and S. Heath, "An in vitro study of ruminal microorganisms influencing lactate turnover and its contribution to volatile fatty acid production," J. Agric. Sci., vol. 103 pp. 37-51, Aug. 1984.

[33] H. D. Hess, R. A. Beuret, M. Lotscher, I. K. Hindrichsen, A Machmuller, J. E. Carulla, C. E. Lascano, and M. Kreuzer, "Ruminal fermentation, methanogenesis and nitrogen utilization of sheep receiving tropical grass hay-concentrate diets offered with Sapindus saponaria fruits and Crratylia argentea foliage," Anim. Sci., vol. 79, pp. 177-189, April 2004.

[34] A. K. Patra and J. Saxena, "A review of the effect and mode of action of saponins on microbial population and fermentation in the rumen and ruminant production," Nutr. Res. Rev., vol. 22, pp. 204-219, Dec. $2009 \mathrm{~b}$.

[35] M. H. Tavendale, L. P. Meagher, D. Pacheco, N. Walker, G. T. Attwood, and S. Sivakumaran, "Methane production from in vitro rumen incubations with Lotus pedumculatus and medicago sativa and effects of extractable condensed tannin fractions on methanogenesis," Anim. Feed Sci. Technol., vol. 123, pp. 403-419, Dec. 2005

[36] A. K. Patra and J. Saxena, "Dietary phytochemicals as rumen modifiers; a review of the effects on microbial populations," Anton. Van Leeuwen, vol. 96, pp. 363-375, Jul. 2009.
[37] C. C. Xu, Y. Cai, J. G. Zhang, and M. Ogawa, "Fermentation quality and nutritive value of a total mixed ration silage containing coffee grounds at ten or twenty percent of dry matter," J. Anim. Sci., vol. 85 , pp. 1024-1029, Dec. 2007.

[38] M. Mishra, F. A. Martz, R. W. Stanley, H. D. Johnson, J. R. Campbell, and E. Hilderbrand, "Effect of diet and ambient temperature humidity on ruminal $\mathrm{pH}$, oxidation reduction potential ammonia and lactic acid in lactating cows," J. Anim. Sci., vol. 30, pp. 1023-1028, Dec. 1970.

[39] J. Marden, P. C. Bayourthe, F. Enjalbert, and R. Moncoulon, "A new device for measuring kinetics of ruminal $\mathrm{pH}$ and redox potential in dairy cattle," J. Dairy Sci., vol. 88, pp. 277-281, Jan. 2005.

[40] R. L. Baldwin and R. S. Emery, "The oxidation reduction potential of rumen contents," J. Dairy Sci., vol. 43, pp. 505-511, Jan. 1960.

Nirosh Dias Senevirathne was bone in Galle, Sri Lanka on $18^{\text {th }}$ February 1976. Currently he is studying at Department of environment hygiene, Obihiro University of Agriculture and Veterinary medicine, Obihiro, Hokkaido, Japan as a MSc (Animal and food hygiene) student. He has obtained BSc (Agriculture) and M.Sc. (Animal Science) from University of Peradeniya, Sri Lanka.

Takahiro Nishida is Associate professor of the Department of environmen hygiene, Obihiro University of Agriculture and Veterinary medicine, Obihiro, Hokkaido, Japan. He has obtained $\mathrm{PhD}$ in Agriculture. Currently, he is guiding research in the field of ruminant nutrition as well as estimate and methods of mitigate methane emission from the ruminants.

Junichi Takahashi is an emeritus professor of the Obihiro University of Agriculture and Veterinary medicine, Obihiro, Hokkaido, Japan. He has obtained $\mathrm{PhD}$ in Agriculture. Currently he is the president of Greenhouse Gases and Animal Agriculture conference.

Kazutaka Umetsu is professor and head of the Department of environment hygiene, Obihiro University of Agriculture and Veterinary medicine, Obihiro, Hokkaido, Japan. He has obtained $\mathrm{PhD}$ in Agriculture. Currently, he is guiding research in the field of bio resource recycling.

Takuya Okamoto is Managing Director of Meiwa sangyo co., Ltd, Kyoto, Japan. 